\title{
Regional Challenges and Competition in the Application of Public Diplomacy in East Asian Countries Year 2008
}

\author{
Callula Salsabillah ${ }^{1}$, Amalia Insan Karimah ${ }^{2}$, Erzalina Widya Kusuma ${ }^{3}$, Zacky Alifirano Pandana ${ }^{4}$ \\ ${ }^{1}$ University of Pembangunan Nasional Veteran East Java, Indonesia \\ ${ }^{2}$ University of Pembangunan Nasional Veteran East Java, Indonesia \\ ${ }^{3}$ University of Pembangunan Nasional Veteran East Java, Indonesia \\ ${ }^{4}$ University of Pembangunan Nasional Veteran East Java, Indonesia
}

Email: Lula.callula4@gmail.com

\section{ARTICLE INFO \\ Date Received: 14 \\ November 2020 \\ Revision Date : 06 \\ December 2020 \\ Date Received : 30 \\ December 2020}

\section{Keywrods:}

public diplomacy; diplomacy; soft power; east asian; china; japan; south korea;

\section{ABSTRACT}

In today's world of international politics, the value for world countries in follow-up with other countries using a ceasefire or military use in a state of persistence has long been abandoned. A new approach in the form of Diplomacy that belongs to the concept of soft power is a more effective and efficient approach if used by various countries, especially to achieve national interests and foreign policy objectives. Various types of Diplomacy are often used but the approach of Public Diplomacy is the priority of various countries, especially in East Asia to exert influence globally and gain the interests of their countries. But in its application, especially in regions that use Public Diplomacy massively, this method can encounter failures or challenges in order to achieve its main objectives. Competition in the use of Public Diplomacy between countries in East Asia becomes an interesting discussion because in the 21 st century, 3 pillar countries of East Asia are promoting diplomacy to the world.

\section{Coresponden Author:}

Email: Lula.callula4@gmail.com Article with open access under license

\section{INTRODUCTION}

Academically, diplomacy is defined as "a As GR Berridge analyzes, the main purpose of diplomacy is "to enable countries to secure their foreign policy goals without the use of violence, propaganda, or the law".(Berridge, 2015). In other words, "diplomacy is a way for countries to achieve their foreign policy"..

The term 'public diplomacy' was raised in 1965 by Edmund Gullion with the definition of "Public diplomacy with regard to the influence of public attitudes towards the establishment and implementation of foreign policy. Includes planting public opinion by the government in other countries, group interaction and national interest in one country with another country; reporting of foreign affairs, as well as its impact on intercultural communication policies and processes" (Cull, 2008)

According to Nye, "public diplomacy is an instrument that governments use to mobilize soft power resources to communicate with and attract the public from other countries, not just their governments". (Nye Jr, 2008).

East Asia is an international region known as the region whose economy is growing fastest in line with the growth of public diplomacy investment and cultural relations that are also growing significantly, but in fact East Asia is also a region vulnerable to conflict and increased tensions between leading neighboring countries, where tensions in the East Asia region can explode at any time and pose a threat of war between countries. Although, East Asia as an international region has produced two of the world's three leading economic powers (Melissen \& Sohn, 2016). With the situation of East Asia region vulnerable to conflict of competition and friction between countries in East Asia, it is not uncommon to damage the image or reputation of a country, therefore public diplomacy becomes a very serious tool to restore a positive image and realize the future of the region.

Many countries have used public diplomacy as a tool to give other countries a good view of their countries. This becomes very important for a country, because of the huge impact of a country's bad image that will affect cooperation relations. One of the uses of public diplomacy has also been used in the early 20 th century by major Countries such as the United Kingdom, the United States, and the Soviet Union also used public diplomacy as their 
attempt to inform and spread their ideology, which it aimed to launch the introduction of their ideology and its spread to other countries.

To achieve the goal that a country wants to aim for, the use of resources used in public diplomacy must also appeal to foreign public. Otherwise, public diplomacy cannot function optimally. As in the three East Asian countries, namely Japan, South Korea, and China are starting to compete to increase their soft power. Japan is valued as a superpower, South Korea as an economic miracle and Hallyu, and China as a military power, high economic competitiveness, and not to miss the role of culture as a source of soft power from each of them.

The People's Republic of China (PRC) as one of the countries in the East Asia region, is also a country that uses public diplomacy to gain a good image in the eyes of the international world. China spends more of its funds to be used in public diplomacy compared to other countries in the Asian region. Noted in media reports, China has spent about \$US9 a year on public diplomacy as well as other activities intended to boost its soft power. In the process of establishing a good image for the country, China has used classic propaganda, such as lending pandas to foreign zoos or by playing "ping-pong diplomacy" with America in an effort to improve China's positive image abroad. However, then in the late 1990s, this ad hoc approach began to be abandoned because it was considered less systematic in building China's positive image and less significant in the use of soft power for the improvement of Chinese public diplomacy (Hall \& Smith, 2013).

The Chicago Council on Global Affairs, also reported that the soft power that has been done by China is far below Japan. So of course, this will affect the public perception of china's political power and soft power. Japan is also a country that successfully enjoys the results of its soft power resources, namely, economic success and also the high level of education among Japanese people, which has become an object of admiration for the whole world. Japan is also the first non-Western country to attract Westerners with japanese technology products such as Toyota, Honda, and Sony. The development of the machinery and electronics industry was initiated by the state, and became the driving force for the rise of Asia which was hit by the economic crisis in the late 20th century. The appeal of Japanese culture, is also an element of Japan's soft power, ranging from fashion, music, design, Japanese food, including anime and manga (comics).

Japan's soft power instruments have come under the control of the Japanese government. The Japanese government has embraced the concept of soft power as a tool in foreign affairs and is used to increase the attractiveness of the country and Japan's national status in the international world.
Japan is also using its public diplomacy to establish symbiotic relations with China and South Korea. (Hall \& Smith, 2013). Namun, ternyata terdapat batasan terhadap Jepang regarding the use of soft power especially in the East Asia region, this is due to Japan's failure to fulfill its imperialistic past. Japan's "unapologetic" foreign policy is highly controversial and an obstacle to Japan's intraregional reconciliation process. This then impacted Japan's soft power, the negative policy was judged to only exacerbate hostility and suspicion towards Japan by its East Asian neighbors. So Japan should have four strong pillars in its use of soft power, namely, military, economic, cultural, and foreign policy.

In addition, since the late 1970s, the Japanese government has been active in increasing its international influence by providing ODA funds to help underdeveloped countries. However, the "cash diplomacy" held by Japan and in the realm of ODA performance, in 2015, has not succeeded in strengthening Japan's international reputation and influence.

South Korea is also one of the three major East Asian powers in carrying out its public diplomacy. South Korean cultural wave or known as "Hallyu", was beginning with the export of television dramas from South Korea, and managed to bring a positive image influence to the popularity of South Korean pop culture in other countries. Along with the increasing economic achievements of South Korea and the success of democracy in the late 1980s, and providing more of a strong foundation for the advancement of public diplomacy i.e. economy, and culture aided by the powerful information technology of South Korean popular culture, such as drama, song, food has succeeded in attracting foreign public to know South Korean culture and then adopted as a tool of public diplomacy (Melissen \& Sohn, 2016).

During lee myung-bak's presidency, from 2008 to 2013, Lee Myungbak was very keen to develop South Korea's soft power by promoting national image as well as national values. Myungbak promised that it would develop a variety of soft power instruments by combining cultural and technological elements that later became South Korea's creative industries, expanding the number of ODA, and contributing to global security and peace. However, unfortunately in the midst of his presidential trip, Myungbak faced difficulties due to South Korea's declining international popularity, over the hostile reaction of North and South Korea. In addition, the south Korean government's increased spread of culture through the "Hall of the Korean Wave" in China and other Asian countries has also drawn criticism from China and sparked a backlash from other countries, which it has seen as an aggressive move by the South Korean government (Melissen \& Sohn, 2016).

In addition, the obstacles to public diplomacy 
that South Korea must face, are the response of the South Korean people who are frustrated with the South Korean government, and criticism of domestic politics that has reached the level of "political phobia", so that the incident again degrades the image of South Korea, because it is considered that South Korea is too concerned with the use of soft power over support on human rights issues, and the success of the democratization process. Therefore, it is necessary to improve South Korea's national image and it requires the development of an active public diplomacy strategy and in accordance with the needs of the country.

This research is expected to contribute to filling the gap in current studies, especially the study of the use of public diplomacy in the East Asia region. The authors hope that this research can contribute as a support for the study of the efforts of countries in the East Asia region in the reconciliation of public diplomacy in the East Asia region since the global financial crisis hit in 2008, so that in 2008 there has been increased public diplomacy activities in the East Asia region collectively which is faster to recover from the crisis than other regions.

political process in which political entities have official relations with each other in the international sphere". Christopher Hill emphasizes the way and purpose of diplomacy that diplomacy is the way to get the path desired by a political entity in international politics, as well as an important instrument for building international stability. (Hill, 2003). Malone pointed to the different purposes of public diplomacy again, he defined it as direct communication with foreigners with the aim of influencing their thinking, as well as their government. (Hill, 2003). The function of diplomacy also includes the creation and implementation of foreign policy; the traditional functions of representation, reporting, communication, negotiation, and maneuvering, as well as taking care of the interests of citizens abroad.

The role of diplomacy in international relations as well as at the domestic level is very important because it is an important variable for peace and conflict South Korea is too concerned with the use of soft power over support on human rights issues, and the success of the democratization process. Therefore, it is necessary to improve South Korea's national image and it requires the development of an active public diplomacy strategy and in accordance with the needs of the country.

This research is expected to contribute to filling the gap in current studies, especially the study of the use of public diplomacy in the East Asia region. The authors hope that this research can contribute as a support for the study of the efforts of countries in the East Asia region in the reconciliation of public diplomacy in the East Asia region since the global financial crisis hit in 2008, so that in 2008 there has been increased public diplomacy activities in the East Asia region collectively which is faster to recover from the crisis than other regions.

political process in which political entities have official relations with each other in the international sphere". Christopher Hill emphasizes the way and purpose of diplomacy that diplomacy is the way to get the path desired by a political entity in international politics, as well as an important instrument for building international stability. (Hill, 2003). Malone pointed to the different purposes of public diplomacy again, he defined it as direct communication with foreigners with the aim of influencing their thinking, as well as their government. (Hill, 2003). The function of diplomacy also includes the creation and implementation of foreign policy; the traditional functions of representation, reporting, communication, negotiation, and maneuvering, as well as taking care of the interests of citizens abroad.

The role of diplomacy in international relations as well as at the domestic level is very important because it is an important variable for peace and conflict.

\section{Literature Review}

The author has reviewed several literature reviews that have related topics or frame of thought that will be written in this research.

The first study found by the authors was a study written by Trisni (2012) with the title "Pencapaian Kepentingan Korea Selatan melalui Diplomasi Publik Korean Wave" (Trisni, Isnarti, Sinulingga, \& Ferdian, 2018) The first study found by the author was a study written by Trisni (2012) with the title where the purpose of this study is to explain the difficulty of South Korea in the formation of pre-existing images due to the problems faced by the South Korean government regarding this image. Image is rated as something important for a country. Big countries are always trying to improve their own image because it can facilitate various interests both economic and other interests, related to their country's policies.

The research uses the concept of Public Diplomacy which explains that the implementation of traditional public diplomacy is government driven where the government plays a big role in the implementation of public diplomacy. It can be concluded that traditional public diplomacy has several supporting components, including (1) the government as the organizer of public diplomacy; (2) Foreign public which is the target as the implementation of diplomacy; (3) information, culture, education and sources of state attractions as media used to conduct public diplomacy; and (4) foreign public interest and impartiality as the purpose of its implementation.

The conclusion that can be drawn from the research is that in general Korean Wave succeeded in achieving the goal of introducing Korean culture to foreign communities. However, Korean Wave has 
not succeeded in achieving the interests desired by the government because the implementation of public diplomacy aimed at achieving the interests of the state must get intense coordination from the government.

The second study was from Veronica (2014) under the title Rivalry China and Japan In East Asian Regional Institutions (Veronica, 2015) with the aim to find out how the area called the grand chessboard from geopolitical struggles has a high competition, especially between the two countries that have the power, namely China and Japan. The concept used by researchers is rivalry by using the perspective of realism.

Two regional powers in east Asia, Japan and China, have great potential to be the driving factors for the establishment of regional institutions in the East Asia region. The interdependence between the two did not stop the rivalry for influence between the two countries. This rivalry is exacerbated by a history of entrenched hostility, distrust, and competition in improving military capabilities that ultimately leads to great competition between the two. Japan and China's leadership rivalry over regional institutions is evident in Japan's efforts to intensify its role in several existing regional institutions to curb China's rapid progress in terms of economy, diplomacy and security in the Asia Pacific region. Meanwhile, China is using multilateral forums in the region to strengthen its position as a new regional power, especially after shifting Japan economically in 2010.

Both China and Japan have obstacles in becoming leaders in the region, especially East Asia. Both countries have to fight hard in gaining confidence and trust from other countries in the region as major players. And put forward trust and good relations over their ambitions as regional leaders amid distrust of other Asian countries.

Japan's obstacles are (1) Japan still faces a bad history during the Pacific war that leaves suspicions from other Asian countries; (2) Japan's proximity to the U.S. becomes an obstacle because the U.S. often makes Japan subservient; (3) As a capitalist democracy, Japan is identified as part of the west which poses a dilemma for Japan to become a bridge between west and east.

While some obstacles owned by China namely (1) China has the nature of bullying in addressing problems, especially disputes; (2) lack of transparency shown by the Chinese government; (3) China's foreign policy tends to be expansive and expansionist.

The third study found by the author was a study from Kamala (2018) titled "Globalization of Japan and Korea Entertainment Industry: Influence on Public Perspectives Between Countries". In his research the authors aim to find out the impact of Industrial Globalization between the two countries. Globalization itself can be interpreted as integrase economy, technology, politics, culture, and social aspects between countries in the world. Because one of the aspects that are strongly affected by globalization is culture.

The theory used in analyzing the problem is Public Diplomacy with the concept of liberalism, as well as soft power diplomacy. Public diplomacy is an inseparable form of diplomacy from soft power. Joseph Nye (2004:5-6) states that soft power as a power is the ability to shape a party's choice.

But the conclusion of the study proves that the use of the entertainment industry as an instrument of public diplomacy by Japan and Korea towards each other has not fully had the effectiveness in changing and influencing the public perspective of the opposing country. It was proven by the negative reaction from the public based on rising tensions between the two countries in 2011 due to the Dokdo-Takeshima dispute issue.

After analyzing several journals, the authors were able to draw conclusions from all three that the public diplomacy that has been conducted by countries in East Asia, especially China and Japan alike - is equally risking the position of leader in the region. The title that the author finally got is "Regional Challenges and Competition in the application of Public Diplomacy in East Asian Countries in 2008".

\section{Theoretical Framework}

To explain the failure to use Public Diplomacy in east Asian countries and efforts to update Public Diplomacy since 2008, the author uses at least two frames of thought that both serve as instruments of influence, namely the Theory of Soft Power by Joseph Nye who is the parent of Public Diplomacy, of which Public Diplomacy is a "child" included in soft power methods. In addition, also the concept of National Interest / National Interest..

In previous Library Reviews it has been explained that some scholars have differences in conceptualizing certain aspects to explain the new Public Diplomacy reconciliation efforts in East Asia. So in order to explain the background, at least the author uses two frames of thought. The first is Soft Power. The concept of Soft Power was first introduced by Joseph S Nye (1990) along with the negation of Soft Power, namely Hard Power. Both are the kind of state power defined by Barnett and Duvall (2005) as the state's ability to use its resources to make other states subservient and do what the state wants resource owners to do. But power or power is defined by Nye as the ownership of certain resources to be able to direct the other party to do what the state resource owner wants, without what element of coercion. 

Soft power can be understood as a latent force and does not appear directly, but the impact can still be felt. Soft power sources can come from the image of a country, such as ideology, policy both domestically and abroad, to the culture that is popular among the world community (Nye 1990). The explanation is contrary to the concept of hard power that provides a very clear and coercive power, such as the military and economic power of a country. In today's contemporary era, there are many shifts in the country's power pattern from hard power to soft power. This is due to the dynamics of contemporary world politics that used to use a lot of hard power, such as during the era of world wars 1 and 2. But in the industrial era as it is today, military power no longer has such a significant influence in the World War era, it is also supported by the many awareness and spirit of peace shown by the countries of the world. The dynamics of the world also lead to interdependence between countries, making new powers such as diplomacy agreements to trade agreements become stronger, so that soft power becomes much more useful at this time. (Nye 1990).

In the present time, there is a significant change in world politics that has affected the importance of soft power and hard power. However, there is little discussion about the condition of decision-making needed for world leaders in effectively using soft power. This paper tries to articulate a more rigorous and systematic understanding of the soft power process, to explain how changes in the international political process have now increased the value of soft power to hard power, and how soft power strategies are increasingly being used by decision makers in their application of foreign policy, as well as in the form of diplomacy by their countries.

\section{National Interest as Effecting Instrument}

The implementation of diplomacy conducted by any country, certainly driven by interests. What is meant by the interest is National Interest, is a national goal that the country wants to achieve. Interest is a need felt by a country in relation to another country that does not belong to its territory. It is the national interest that encourages a great contribution to the formation of views and approaches that a country can make. According to Norman J. Padelford (1960), the national interest is; "National interest of a country is what a governmental leader and in large degree also what it's people consider at any time to be vital to their national independence, way of life, territorial security and economic welfare.".

The national interest according to Donald E. Nuchterlain (1978) is divided into four points, namely; Defense Interest which is in the interest to protect the country and its people from physical or military threats from other countries or is a form of protection from threats to the system of a country. The second economic interest is economic interests in the form of economic-financial value increase in relation to other countries, where trade relations conducted with other countries will provide economic benefits. Then the third World Order Interest is the national interest that aims to influence and desire the country's diplomacy actors to get a good image and the impression of an established country, as well as guarantee the maintenance of the political system - the international economy so that a country can feel security so that the country can operate outside its territorial boundaries. And the latter is ideological interest, is the interest of spreading or defending ideology against a certain set of values that can be held by society.

\section{METHOD}

In this research, using descriptive qualitative method with case study approach, because in this study would like to see how the efforts of countries in East Asia, especially China, Japan, and South Korea are the strongest countries, in an effort to reconcile public diplomacy in the East Asia region in 2008. The selection of qualitative descriptive methodology aims to describe a phenomenon that in this case is how the efforts of countries in the East Asia region to reconcile their public diplomacy.

This descriptive research method is a research method that seeks to solve problems or answer any questions of the problem at hand. Meanwhile, this qualitative approach is assumed to be an approach aimed at understanding social phenomena from a perspective that involves the involvement of the lives of actors. As Sukidin and Basrowi (2002) said (Sukidin, 2002) that "Qualitative research is one of the research procedures that produce descriptive data in the form of speech or writing and behavior of observed people. Through qualitative research, researchers can recognize subjects and feel what they are experiencing in everyday life. Qualitative research is expected to produce an in-depth description of speech, writing, and/or observable behavior from an individual, group, community, and/or a particular organization in a specific context setting that is studied from a whole, comprehensive, and holistic point of view."

In using descriptive qualitative research method, in choosing data source using data collection technique with secondary data type. This case study data can be obtained indirectly from the study subjects. Secondary data is data obtained from other parties, not directly obtained from researchers from the subject of his research which is usually in the form of documents or reports (Azwar, 1998). Secondary data is what helps to provide a comprehensive discussion on the topic of Public Diplomacy in the East Asia region.

Researchers choose to use secondary data because in this problem the required data already exists and researchers only collect and analyze data 
according to the problems raised by the author. In this case, researchers used the official websites of the governments of Japan, South Korea, and China in conducting their public diplomacy efforts as secondary data because the data could be accounted for. Therefore, as a research instrument, using secondary data in this problem can be accessed from official reports or websites to scientific journals, books and related articles, and newspapers.

\section{RESULT AND DISCUSSION}

In accordance with the presentation of the above frame of thought, actualization of the National Interest of a country certainly influences the implementation of state diplomacy in shaping the country's public opinion. The establishment of public opinion as a manifestation of Public Diplomacy can be categorized as a Soft Power. So it can be concluded that from the exposure of soft power theory and national interest above, it can be described that the influence of Soft Power on public perception of a country has a great contribution. This can be seen as in the following table;

Source: Lee, Jong Sook and Melissen, Jan. 2011. Public Diplomacy and Soft Power in East Asia

Compared to the other 2 countries namely Indonesia and Vietnam which are still in the same continent, the perception between other countries towards China, Japan and South Korea is quite highly categorized. And this table shows that of the three dominant countries in the East Asia region, China has the lowest image rate. This fact can be the main reason why china is currently the most developed country with Soft Power method with approach through Public Diplomacy as its main choice compared to other East Asian countries or even various countries in the world. Also, China's ambition to become an emerging power to rival the hegemony of the United States in the world.

In addition to identifying the experiments of Public Diplomacy in east Asian countries that are largely dominated by China, and how the efforts of East Asian countries such as Japan, South Korea and China organize new efforts in public diplomacy both in building soft power assets ranging from 16 music art to historical figures and cultural values. These countries invest in public diplomacy by strengthening public diplomatic institutions within government ministries, establishing cultural centers abroad, spreading their own values and national interests. These efforts have increased phenomena since the global financial crisis in 2008 that hit the economies of countries in the world occurred, the East Asia region also felt the impact. In order to restore economic status, East Asian countries collectively began to use this method of diplomacy. Japan's Public Diplomacy

For more than a century, Japan has aspired to achieve "superpower" status in both global maupub regions. In contrast to the emerging power of China and India, in terms of economic and military strength and global influence, the decline of Jepan's economic power puts it in second place after the United States. This has caused Japan's priorities to shift, because although Japan disputes its validity to project an image of itself as middle power (Holbraad, 1971). Japan is looking for its own way to become an interesting force. In this era of globalization, Japan feels it is necessary to be identified as a credible member of the international community. Given the value of the word and perception of current diplomacy, Japan needs to clarify its understanding of the term soft power and quickly find the best terms to describe what the country it believes in. Historically, Japan has frequently colonized neighboring countries, as a reminder that Japan must face this problem directly and hold dialogue, especially with its closest neighbor in Asia who has a negative view of its national image (Yoshihide, 2005).

Such bilateral efforts may not be sufficient and may require increased regional cooperation along the East Asia region, stretching from the Okhotsk Sea at least to the South China Sea. Meanwhile, the growing interaction in the region creates the same Asian culture in the sense of lifestyle: people enjoy similar music, fashion, series and TV dramas, overseas travel, and other cultures of the region. Such interactions are key to building communities and, if regional communities are to be established and regional cooperation is achieved, Asian communities will have greater opportunities to interact, which will help in developing individual national and regional identities. Through functional cooperation in trade, finance, climate change, and environmental matters, as well as health is regulated according to Japanese preferences, helping to turn antipathy into empathy (Yoshihide, 2005). Any approach that allows Japan to overcome its parochial nationalism and move to help boost regional public interest may prove the way to close the gap between Asia's preference for Japanese cultural products and Japan's negative image. This will be Japan's best public diplomacy achievement in the twenty-first century. 
South Korea's Public Diplomacy

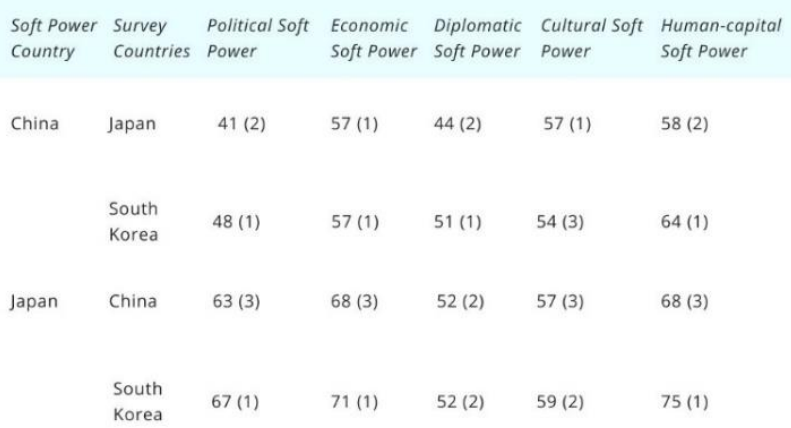

Source: CCGA, Soft Power in Asia: Results of a 2008 Multinational Survey of Public Opinion, p. 3

South Koreans view Japan's soft power as quite attractive. Japan's political, economic and human resources soft power is viewed more positively by South Koreans than Chinese. For soft power aimed at politics, South Koreans view Japan as preferable to China because it "respects human rights and legal supremacy" (an average score of 65 versus 40 ), and because it has a "political system that serves the needs of its people". For diplomatic soft power, South Koreans view Japan as slightly preferable to China for issues such as building trust in international institutions, solving problems in Asia, and promoting politics to people in Asia. But the effectiveness of Japan's policy is considered inferior to China's for two substantive policies: 43.3 percent of South Koreans view China as effective in resolving the North Korean nuclear issue, while only 31.1 percent of Koreans think that Japan is effective; and to manage cross-strait conflict, 42.8 percent of South Koreans think that China is effective, while only 20.4 percent think that Japan is effective. For cultural areas, South Koreans view Japanese popular culture and its spread as less negative than Chinese popular culture: 56.5 percent of South Koreans view the spread of Chinese cultural influence in Asia negatively, compared with 53.3 percent for the spread of Japanese people's cultural influence. Japanese popular culture appeals more to South Koreans than Chinese popular culture, and Japanese popular culture's influence over South Korean popular culture feels stronger (average score of 57) than Chinese popular culture (average score of 4). If economic interests are taken as proxies of hard power, South Korea's FreeTrade Agreements/FTA policy options are in line with soft power in the economy. South Koreans view economic relations as trade and investment, with the United States and China almost as important (Chun, 2008). However, Japan is preferred as an FTA partner by South Korea, although trade and investment with China is considered more important than with Japan. Therefore, the FTA's policy choices as opposed to intuition by South Koreans in Japan over China seem to be explained by the perception of china's lower economic soft power (Lee, 2005).

China's Public Diplomacy
In the early 2000s when China took the initiative in connecting neighboring countries to its economic network, Japan quickly reacted by calling for an "East Asian Community". The People's Republic of China (PRC) now seems to spend more money than any other Asian country to use in public diplomacy. According to media reports, China has spent nearly $\$ 9$ billion a year on public diplomacy and other activities intended to boost its soft power.

In the past, the Chinese government used classical propaganda and other acts of public diplomacy, such as lending pandas to foreign zoos or playing "Ping-pong diplomacy" with America in an effort to improve its image abroad. However, in the late 1990s, this ad hoc approach was abandoned when policymakers began to think more systematically about how to build and use soft power leading to a significant increase in Chinese public diplomacy.

In terms of public diplomacy, China's efforts as a successful competing option depend on counter-narrative construction. China's strength is largely economic, but its economic achievements produce mixed results in the field of soft power. But power produces not only power but also vulnerability, as a recent report on the financial crisis and soft power in East Asia succinctly states if a country's economic and military power increases, its soft power is at risk (Keidel, 2008). It is difficult for China to accept the fact that foreign perceptions cannot be regulated and that China's national government is not in a position to control the image projected by their own society. China has successively approached public diplomacy in both international and domestic contexts, where it is expected to contribute to national cohesion and generate support for China's foreign policy goals (Kurlantzick, 2007).

There is little doubt that in targeting audiences, China's soft power tends to succeed in the "Global South". But the conclusion that the socalled "Beijing Consensus" succeeds for China in developing countries is untested by the running of time. Soft Power South Korea is indeed much stronger than China. Asian and European attitudes towards China are not as positive as various sources assume, there is no strong narrative of normative power affecting China's reputation in European countries such as The United Kingdom, France and Germany. It turns out that western countries are reluctant to accept China's soft power influence and European and American prejudices further complicate China's public diplomacy in an attempt to change it. Although China's foreign aid is a soft power resource in developing countries, western concerns have arisen about the economic impact of China's rise to greater since the 2008 financial crisis (Barboza, 2008). The relationship between China and Taiwan is a great example of what is going well. Europe's perception of China is a 
good case study of what doesn't work and its implications, what is needed.

\section{CONCLUSION}

Countries in East Asia compete to build and use soft power using public diplomacy. Many seek to build soft power assets ranging from music art to historical figures and cultural values. These countries invest in public diplomacy by strengthening public diplomatic institutions, establishing cultural centers abroad, spreading their own values and national interests, spreading culinary specialties, and expanding academic and educational exchanges. All of these measures aim to influence public opinion in other countries to gain support for the country's own foreign policy goals. One important area where East Asian countries use soft power is projecting their regional vision. Increased dependency and Asian relations in trade, investment, and finance have made their governments realize that East Asia is a big part of where their fate is closely related to regional prosperity. Since the global financial crisis of 2008, as diplomacy has improved, East Asian economies have collectively grown faster than any other region, and quickly recovered from the crisis.

Nevertheless, the most striking result is that there is little positive correlation between the investment asian countries have made in public diplomacy and how foreign entities elsewhere in the region tend to view it. This observation is particularly striking with regard to China, as it has invested more than most other countries in trying to create and use soft power through public diplomacy. The future of new public diplomacy in East Asia therefore lies in international and transnational dialogue. By definition, government has a role to play in a country's public diplomacy. The importance of communicative action and a more widespread socialization process in East Asia should not be underestimated. In such perspective, soft power is a national asset, but not inferior to relationship-based quality that has the capacity to help the development and cooperation of communities in the region (Chiba et al., 2009). For Japan, South Korea, China and Taiwan it seems clear that improved community-to-community relations can help strengthen their soft power.

\section{REFERENCES}

Barboza, David. (2008). China unveils sweeping plan for economy. New York Times, 9.

Berridge, Geoff R. (2015). Diplomacy: theory and practice. Springer.

Chiba, Naoko, Murayama, Somay Y., Morozumi, Miyuki, Nakayama, Eiichi, Okada, Takafumi, Iwata, Satoshi, Sunakawa, Keisuke, \& Ubukata, Kimiko. (2009). Rapid detection of eight causative pathogens for the diagnosis of bacterial meningitis by real-time PCR. Journal of Infection and Chemotherapy, 15(2), 92-98.

Cull, Nicholas J. (2008). Public diplomacy before Gullion: The evolution of a phrase. In Routledge handbook of public diplomacy (pp. 39-43). Routledge.

Confucius Institute Online. Introduction to the Confucius Institutes (August 2009). Available at http://www.college.chinese.cn/en/article/200908/29/content_22308.htm

Hall, lan, \& Smith, Frank. (2013). The struggle for soft power in Asia: Public diplomacy and regional competition. Asian Security, 9(1), 118.

Hill, Christopher. (2003). The changing politics of foreign policy. Palgrave Macmillan.

Hongying, Wang and Yeh-Chung Lu. The Conception of Soft Power and Its Policy Implications: A Comparative Study of China and Taiwan. Journal of Contemporary China Vol. 15, No. 56 (2008), p. 438.

Jerry S. Carlson and Keith F. Widaman. The Effects of Study Abroad during College on Attitudes toward Other Cultures. International Journal of Intercultural Relations Vol. 12 (1988), pp. 1-17.

Keidel, Albert. (2008). China's Economic Rise: Fact and Fiction. Carnegie Endowment for International Peace.

Kurlantzick. Charm Offensive, pp. 76-78 and p. 125.

Lee, Sook J and Mellisen, Jan. Public Diplomacy and Soft Power in East Asia (Hamsphire: Palgrave Macmillian, 2011)

Mitsuyo Ando and Fukunari Kimura. How did Japanese Exports Respond to Two Crises in the International Production Networks?. Asian Economic Journal, vol. 16, no. 3 (2012).

Melissen, Jan, \& Sohn, Yul. (2016). Understanding public diplomacy in East Asia: Middle powers in a troubled region. Springer.

Nye Jr, Joseph S. (2008). Public diplomacy and soft power. The Annals of the American Academy of Political and Social Science, 616(1), 94109.

Simon Anholt. Nation-Branding in Asia. Place Branding and Public Diplomacy Vol. 4 (2008), 
pp. $265-269$

Sukidin, Basrowi. (2002). Metode Penelitian Kualitatif Perspektif Mikro. Surabaya: Insan Cendekia.

Trisni, Sofia, Isnarti, Rika, Sinulingga, Anita Afriani, \& Ferdian, Ferdian. (2018). Pencapaian Kepentingan Korea Selatan melalui Diplomasi
Publik Korean Wave. Global Strategis, 12(2), 131-142.

Veronica, Nuri Widiastuti. (2015). Rivalitas Cina dan Jepang dalam Institusi Regional Asia Timur. Global: Jurnal Politik Internasional, 16(1), 1933. 